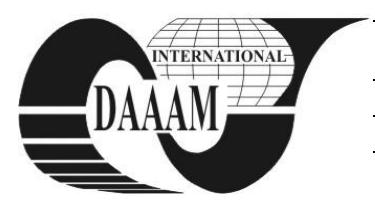

Annals of DAAAM for 2012 \& Proceedings of the 23rd International DAAAM Symposium, Volume 23, No.1, ISSN 2304-1382 ISBN 978-3-901509-91-9, CDROM version, Ed. B. Katalinic, Published by DAAAM International, Vienna, Austria, EU, 2012 Make Harmony between Technology and Nature, and Your Mind will Fly Free as a Bird Annals \& Proceedings of DAAAM International 2012

\title{
SIMPLIFIED ALGORITHM FOR THE USE OF MH-2 CURRENT-METER
}

\author{
VARTOLOMEI, F[lorin] \& BENEA, I[onel]
}

\begin{abstract}
The purpose of this paper is to improve the calculation algorithm for measuring the speed of water streams using the analytical method and the classical current-meter. The case study taken as example is based on the methodology used for working with the MH-2 current-meter manufactured by The Laboratory for Environment Apparatuses - Sibiu, Romania. The calculation matrix we propose aims to severely shorten the time allocated for samplings and to eliminate the errors that may occur in the process of river discharge calculation. The example presented as a table in the $4^{\text {th }}$ section is designed for a timed sampling period of 60 seconds and water speeds that give 300-600 rotations of the current-meter propeller. The index noted $\boldsymbol{n}$ in the results of the matrix is further used for an easier calculation of the water speeds in the sampling points by substituting it in the calibration equation of the current-meter.
\end{abstract}

Keywords: matrix, punctual speed of water, calculation algorithm, classical current-meter, analytical method

\section{INTRODUCTION}

This paper was born from the authors' desire to significantly improve, in time consuming terms, the process/methodology of measuring the speed of water streams using the technique involving the classical current-meter $\mathrm{MH}-2$ manufactured in Romania. The speed of water measured using this method is part of the algorithm for the calculation of the liquid discharge of the rivers given by the general formula [1]:

$$
\boldsymbol{Q}=\boldsymbol{\Omega} * \boldsymbol{v}
$$

where:

$\boldsymbol{Q}$ is the liquid discharge (cub.meters/sec.);

$\boldsymbol{\Omega}$ is the surface of the active section (sq.m) and

$\boldsymbol{v}$ is the speed of water in the active section $(\mathrm{m} / \mathrm{sec})$.

The necessity to do this improvement is the result of the evaluation of the work done by the hydrometric operators, but also of our own experience in this field.

The applicability of this idea is addressed to all personnel involved in measuring and processing of hydrological parameters, especially of liquid and solid discharges and other parameters characterizing the flow of rivers [2].

The domain of the hydrometrical activities in Romania is governed by a legislative framework that brings under regulation the principles and methods applicable to this matter. The most important of these are: The Decree of the Ministry of Waters, Forests and Environment Protection 358/1998 regarding the approbation of "The Reference Book for the Hydrometric
Stations on Romania's Rivers", The Decree of the Ministry of Waters, Forests and Environment Protection 77/1996 regarding the approbation of "The Reference Book for the Organizing and Program of the Hydrometrical Activities on Rivers" and The Decree of the Ministry of Waters, Forests and Environment Protection 56/1997 regarding the approbation of "The Reference Book for Hydrometric Stations and Activities. Water Discharges and Load" [3, 4 and 5].

On the other hand, in daily reality, there are about 600 hydrological stations and 200 pluviometrical stations that are functioning in Romania and most of them (approx. 85\%) are still using classical hydrometric instrumentation, and only $15 \%$ have been equipped with automatic equipment (tab. 1).

\begin{tabular}{|c|c|c|}
\hline $\begin{array}{c}\text { Implementation } \\
\text { Project }\end{array}$ & $\begin{array}{c}\text { Automatic } \\
\text { stations }\end{array}$ & Hydrological area \\
\hline Life Mosym & 35 & Arges, Vedea, Mures, Siret \\
\hline Riverlife & 30 & Timis, Bega \\
\hline Moldova & 2 & $\begin{array}{c}\text { Prut (hydrologic stations } \\
\text { Ungheni and Dranceni ) }\end{array}$ \\
\hline MOSES & 9 & Tisa \\
\hline FLOODMED & 3 & $\begin{array}{c}\text { Bistrita (+ sensors for water } \\
\text { quality) }\end{array}$ \\
\hline DIMINISH & 3 & $\begin{array}{c}\text { Bucharest area (monitoring } \\
\text { of waste waters) }\end{array}$ \\
\hline Urbwater & & Lapus \\
\hline DESWAT & $\begin{array}{c}\text { 2 evaporimeters } \\
\text { 4 hydrological } \\
\text { with sensos for } \\
\text { humidity }\end{array}$ & \\
\hline Others & & \\
\hline
\end{tabular}

Tab. 1. Automatic stations installed up to present [6]

At local levels, Water District Authorities have recently installed some more automatic stations, as a result of their necessity to obtain real-time data.

The prognosis departments of the National Authorities in this field permanently ask for the necessity of increasing the volume of data they use for calibrating and running the Romanian simulation models (VIDRA, CONSUL, UNDA etc) [7 and 8].

Taking into account the rate of installation of automatic station, we foresee a significant number of years for the use of the faster methodology to measure the speed of water streams using the classical currentmeter that makes the subject of this paper.

We have to mention that the first classical currentmeter was built by Woltman in 1947 [9].

Presently, there are used many other types of currentmeters, most spread in Romania being the Jestovski 3, Olt-V and MH-2 types [10]. 


\section{MATERIALS AND METHOD}

This paper addresses especially to the operators working in hydrological stations equipped with classical Romanian made current-meters of $\mathrm{MH}-2$ type, used to measure the speed of water flow. The apparatus is build by The Laboratory for Environment Apparatuses - Sibiu and is specially designed for measuring the speed of the stream flow [11].

The discharge is calculated on the basis if these steam flow speeds, using also the surface of the active section determined by depth survey, as in equation (1). The MH2 current meter consists of an ensemble of three main components: the propeller with rotor, body and empennage for direction or tail (Fig. 1).

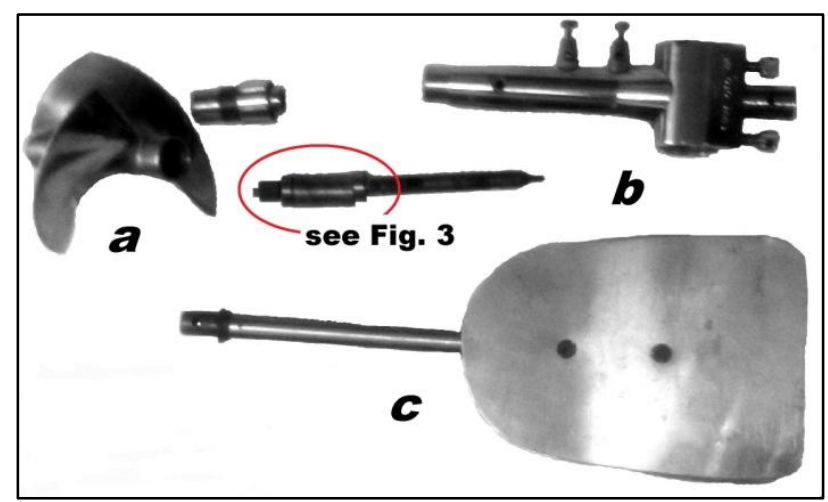

Fig. 1. Main components of the MH-2 current-meter

The current-meter used for this study offers the most convenient possibility for determining the speed of the streams of water, given the limit of use between 0.08 and $5.0 \mathrm{~m} / \mathrm{sec}$. The accuracy guaranteed by the manufacturer is $10 \%$ for stream speeds lower than $0.1 \mathrm{~m} / \mathrm{sec}$ and $10 \%$ for the speeds higher than this [12].

The weight of the whole ensemble when ready to use is 4.9 kilograms. The principle of functioning of the MH2 current-meter relies on catching water movement speed by the propeller (Fig.1.a) that is fixed in the front part of the horizontal axis (Fig 1. b) and turning it into a rotational movement. The rotational speed of the propeller is directly proportional to the speed of the water stream (Fig. 2) [13].

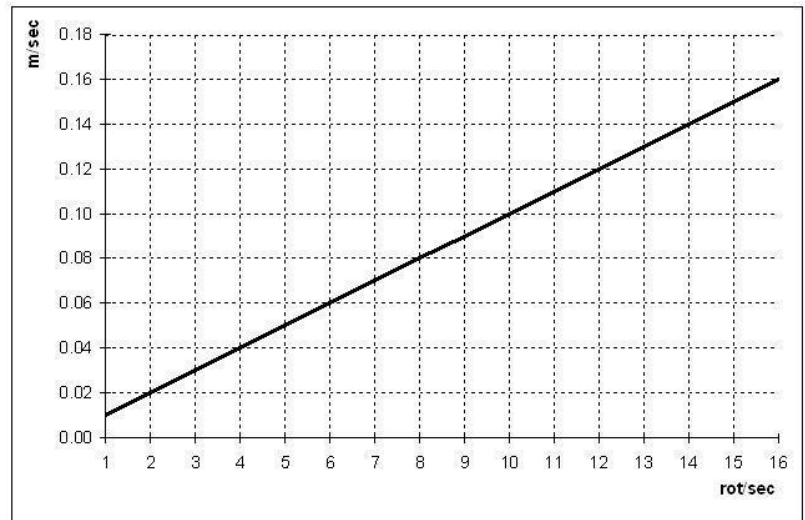

Fig. 2.The relationship between the speed of the water stream and the rotation speed of the propeller of $\mathrm{MH}-2$ current-meter

The number of rotations the propeller does in a unit of time is transformed in electric signals that are transmitted to the signaling device.
The propeller with 2 pallets has a diameter of 100 $\mathrm{mm}$ and was designed such as to give an electric impulse for each set of 20 completed rotations (Fig. 3).

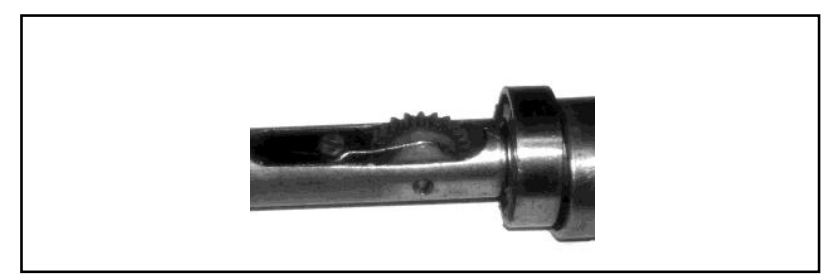

Fig. 3. The device that generates an electric signal for 20 rotations

The ratio of the water current speed and the speed of rotation of the propeller is established for each device in part through laboratory calibration by the manufacturer, under strictly controlled conditions [14]. This ratio is recorded in the form of a set of equations in the calibration certificate that accompanies the MH-2.

For the current-meter used for this study, the calibration equations recorded in the Bulletin of metrology verification nr. 12988 [12] are:

a. for water depths $\leq$ of $1.308 \mathrm{~m}$ :

$$
v=0.1555 * n+0.044
$$

where:

$\boldsymbol{v}$ is the water current speed;

$n$ is the number of propeller rotations and

0.1555 and 0.044 are the calibration coefficients.

b. for water depths < of $1.308 \mathrm{~m}$ :

$$
v=0.1796 * n+0.012
$$

where:

$v$ is the water current speed;

$n$ is the number of propeller rotations and

0.11796 and 0.012 are the calibration coefficients.

From the experience we gained in field works with $\mathrm{MH}-2$, the equation (2) is most often used. Using MH-2 in a manner that is non-compliant with the technical instructions can induce errors in the calculation of the final discharge of up to $20-30 \%$ for the same active section of the river [12].

\section{THE CHALLENGE - A TIME CONSUMING METHODOLOGY}

There is a linear-type relation between the punctual speeds of the thread of water $(v)$ and the number of propeller rotations $(n)$ that has the general form as [15]:

$$
v=a+n * b
$$

where:

$v$ is the punctual speeds of the thread of water;

$n$ is the number of propeller rotations and $a$ and $b$ are calibration coefficients (see eq. 2 , in section 1).

Practically, the current-meter is immersed in the stream of water such as to reach the targeted depth point and oriented with the propeller heading upstream. The MH-2 current-meter once immersed transforms, by means of the propeller, the horizontal speed of the 
threads of water into rotation speed. The propeller is allowed to rotate for minimum 60 seconds and maximum 120 seconds. During this timed interval for observation $(t)$, a number of signals $(s)$ will be registered [11].

The sum of rotations performed by the propeller during the timed period of observation is calculated by multiplying the number of readings at the timer (i.e. the number of signals $(s)$ obtained during the measurement) with 20, according with the principle of operation presented in section 2 .

$$
\sum \operatorname{rot}=s * 20
$$

where:

$\Sigma r o t$ is the sum of the rotation of the propeller and $S$ is the number of recorded signals.

The value of $n$ representing the punctual speed in equation (2) is then calculated using the formula [16]:

$$
n=\frac{\sum r o t}{t}
$$

where:

$n$ is the number of propeller rotations (rotations/sec.);

$\Sigma r o t$ is the sum of the rotation of the propeller and

$t$ is the timed interval for observation of punctual speed in the targeted point of depth.

The value of $n$ thus obtained is then substituted in the calibration equation (2), the result of which will give the punctual speed in the targeted point of depth $(v)$. The measurement of these punctual speeds in targeted point of depth is done along speed verticals the number of which is given by the width of the river (Tab. 2).

But since each vertical for speed survey has variable depth $(h)$, a number of standardized measuring points has to be set along each of them, in order to operate the current-meter and calculate the speed if the water threads.

According to Diaconu C. [17], these points are to be set as it follows: at the surface of the water stream, at $0.2 * h, 0.6 * h, 0.8^{*} h$ and close to the riverbed, thus obtaining the correspondent speeds, respectively: the speed at the surface $\left(v_{s}\right)$, the speeds at $0.2 * h\left(v_{0.2 * h}\right)$, at $0.6 * h\left(v_{0.6 * h}\right)$, at $0.8 * h\left(v_{0.8 * h}\right)$ and the speed at the bottom $\left(v_{f}\right)$.

\begin{tabular}{|c|c|}
\hline River's width $(w)$ (meters) & Number of speed verticals \\
\hline$w<1.0$ & $5-8$ \\
\hline $1.0<w \leq 50.0$ & $8-10$ \\
\hline $50.0<w \leq 100.0$ & $10-15$ \\
\hline$w>100.0$ & 15 \\
\hline
\end{tabular}

Tab. 2. The number of speed verticals as function of river's width

Source: Giurma I., Craciun I., Giurma-Handley R-C., (2001) -

"Hidrologie si hidrogeologie- aplicatii", Ed. "Gh.Asachi", Iasi [9] (taken from Diaconu, C., 1999) [17].

The point considered at the surface is actually $1 \mathrm{~cm}$ below the water surface and the point at the riverbed is 1 $\mathrm{cm}$ above it. This is to avoid registration errors and to ensure that the propeller is registering only the pulsations of the stream of water.

In literature reviews there are to be found several models that give the relation between the number of sampling points and the depth of the speed verticals [18].
The number of operating points for calculating water speed for each vertical of survey is directly related to the

\begin{tabular}{|c|c|c|}
\hline \multirow{2}{*}{$\begin{array}{l}\text { Depth of vertical for } \\
\text { speed survey }(h) \\
\text { (meters) }\end{array}$} & \multicolumn{2}{|c|}{ Sampling points and corresponding speeds } \\
\hline & $\begin{array}{l}\text { Number of } \\
\text { points }\end{array}$ & Corresponding speeds \\
\hline$h>0.8$ & 5 & $\begin{array}{c}v_{s} ; v_{0.2 * h} ; v_{0.6 * h} \\
v_{0.8 * h} ; v_{f}\end{array}$ \\
\hline $0.4<h \leq 0.8$ & 3 & $v_{0.2 * h} ; v_{0.6 * h} ; v_{0.8 * h}$ \\
\hline $0.2<h \leq 0.4$ & 2 & $v_{s} ; v_{f}$ \\
\hline $0.15<h \leq 0.2$ & 1 & $v_{0.6 * h}$ \\
\hline$h \leq 0.15$ & 0 & - \\
\hline
\end{tabular}
depth of it, as mentioned in Tab. 3.

Tab. 3. The number operating points as function if verticals of survey depth [19].

We adopted for this study the formula given by Zavoianu [19], since it is the most suitable for the rivers in hilly or mountainous regions.

The analytical method for calculating the mean speed $v_{\text {med }}$ for a vertical of survey implies the use of the formulae given in Tab. 4.

\begin{tabular}{|c|c|}
\hline $\begin{array}{c}\text { Number of sampling } \\
\text { points } \\
\text { (see Tab.3) }\end{array}$ & $\begin{array}{c}\text { Calculus formula for the mean speed } \\
\left(v_{m e d}\right) \text { in } \mathrm{m} / \mathrm{sec} .\end{array}$ \\
\hline 5 & $v_{\text {med }=\frac{v_{s+} 3 v_{0.2 * h}+3 v_{0.6 * h}+2 v_{0.8 * h}+v_{f}}{10}}$ \\
\hline 3 & $v_{\text {med }=\frac{v_{0.2 * h}+2 v_{0.6 * h}+v_{0.8 * h}}{4}}$ \\
\hline 2 & $v_{\text {med }}=\frac{v_{s+} v_{f}}{2}$ \\
\hline 1 & $v_{\text {med }}=v_{0.6 * h}$ \\
\hline
\end{tabular}

Tab. 4. The number operating points as function if verticals of survey depth [19].

Fig. 4 illustrates the different shares granted for calculation to the punctual speeds along verticals of survey. One can easily notice that greater shares are given to the speeds measured at the sampling points situated at $0.2 * h, 0.6 * h$ and $0.8 * h$, while the smallest ones correspond to the points considered at the surface and the bottom of the water stream. This is explicable by the fact that the mass of water running at the middle of the vertical of survey gives the actual speed (in area marked with $v_{i}$ in Fig. 4) and speeds at the extreme points are diminished because of water friction against the air (case of $v_{s}$ ), respectively against the riverbed $\left(v_{f}\right)$.

Following this algorithm, it results that the mean speed $v_{\text {med }}$ for a vertical of survey is actually considered a linear speed. These linear speeds will be then used to calculate the mean speeds for the partial surfaces between the verticals of survey. In this case, there are two situations [20]:

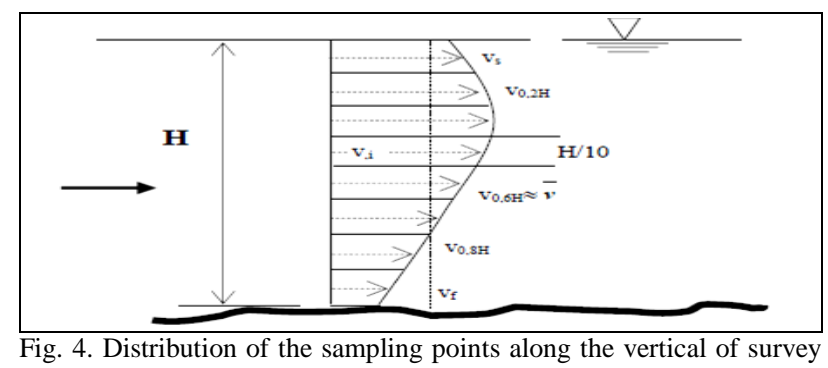
[10]

- the speeds for the partial surfaces from the river bank to the first vertical of survey, as well as the partial 
surface between the last vertical of survey and the opposite river bank is considered to be two thirds $(2 / 3)$ of the value resulted from calculation for the linear speeds of the first, respectively the last vertical of survey.

- the speeds for the partial surfaces delineated by verticals of speed are calculated as arithmetic means of linear speeds for each pair of consecutive verticals of survey.

The limitations our research faced can be divided in two categories: theoretical and methodological limitations and technical-practical originated ones.

The theoretical and methodological limitations are generated, at first, by the diversity of opinions of most cited authors in the field of hydrometrics in respect to: the number of speed verticals as function of river's width, the number operating points as function if verticals of survey depth and the different shares granted for calculation to the punctual speeds along verticals of survey $[3,10,11,14,17,19]$.

Secondly, out of the five classical method for measuring the speed of water streams: analythical, graphical-analythical, graphical-mechanical, integrated and of speed disptribution [9], the simplified methodology proposed in this paper is applicable only for the first and the second ones. The last three methods are most frequently used by the stations equipped with automatic current-meters.

The technical-practical limitations are conditioned by the strict observance of the rules of use and maintenance of classical current-meters [12]. Moreover, from the practical experience of the hydrometrical operators it results that most of the measuring errors are due, on one hand, to the age of the equipments and, on the other, to the high degree of complexity of the calculation algorithm.

\section{THE SOLUTION}

In authors' approach, the simplification of the standard methodology [3, 10, 11, 12, 14, 17, 19], which is the subject of this paper, aimed primarily to identify those stages that generate the most consistant errors found in the final results of the measurements and those being the most time consuming during mesurement procedures. There have been identified, as error generating, the stages implying the calculus of the sum of the rotations of the propeller ( $\Sigma$ rot $)$ from equation 5 (caused by the reading errors of timed interval $t$ for observation and the recording of signals given by the current-meter) and the calculation of the number of propeller rotations $\boldsymbol{n}$ (equation 6). We also noticed that exactly the same two stages are the most time consuming in daily program of the hydrometrical activities [4].

Due to the limitations induced by the methodology presented in section 3, we considered the necessity of a consistent improvement of the algorithm for calculating the linear speeds $\boldsymbol{v}_{\text {med }}$ for the verticals of survey. For this purpose, the paper presents a matrix for calculating the values of the variable $\boldsymbol{n}$ from equation (2) that is further used to find out the speeds of the threads of water at the sampling points. Applying this computing matrix will result in substantial simplification of calculations relating to the standard algorithm, by merging certain operations.

The matrix synthesizes between the timed interval for

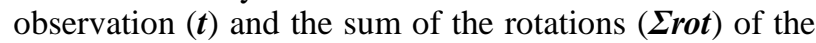
propeller during this period of time. The practical advantage of using this matrix is to faster obtain, during the field samplings, the value of the variable $\boldsymbol{n}$ (the number of propeller rotations). As presented on previous page in Tab. 5 (parts 1 and 2), the matrix has been built for thread of water speeds recorded with a number of 15 30 signals $(s)$ and a timed interval of observation from 60 to 120 seconds.

\section{Example of calculation:}

Given a set of measurements at a hydrometric station the timed period of sampling was 70 seconds, a number of 4 readings were made on the timer.

A constant of 5 signals was noticed (thus respecting the rule of the 15 standard seconds to record the number of the initial signals $s$ ).

The sum of rotations 5 rot obtained using equation (5) is therefore 400 .

These 2 parameters: timed period of sampling $(t)$ and sum of rotations ( $\left.\sum r o t\right)$ are then introduced in the matrix given in Tab. 5 to automatically obtain the value of $n$ $(n=5.71)$. The value of $n$ thus obtained is introduced in equation (2), presented in section 1 :

$$
v=0,1555 * 5,71+0,044
$$

and the punctual speed of water stream is:

$$
v=0,93
$$

As a result of our long practice in the field, we noticed that for the rivers in Romania having depths less than or equal with 1.5 meters, the optimal timed interval of observation $(t)$ for calculating the number of propeller rotations $(\boldsymbol{n})$ is between 60 and 120 seconds and the sum of the propeller rotations ( $\boldsymbol{\Sigma} \boldsymbol{r} \boldsymbol{r o t}$ ) varies between 300-600 rotations. The applicability of the solution presented in this paper is justified based on existing limitations in the practice of measurements at the hydrometrical stations equipped with classical current-meters:

- most stations have classical instruments;

- the degree of training of the operational stuff;

- the experience gained by the hydro-technician;

- technician's ability to accurately follow a laborious algorithm of calculations that is time consuming.

\section{CONCLUSIONS}

Due to the large share of the hilly regions in global and solid runoff in Romania, it results the need to increase, both in time and in space, the stations for measuring the river water speeds and, consequently, rivers' discharges [21, 22, 23 and 24].

Since a considerable large number of hydrometrical stations are situated in the mountainous or hilly regions, the time consumed for samplings is limited by specific weather conditions and the torrential or semi-torrential regime of the runoff [25]. 


\begin{tabular}{|c|c|c|c|c|c|c|c|c|}
\hline $\begin{array}{l}\text { Erot } \\
\text { Time (\$) }\end{array}$ & 300 & 320 & 340 & 360 & 380 & 400 & 420 & 440 \\
\hline 60 & 5,00 & 5,33 & 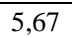 & 6,00 & 6,33 & 6,67 & 7,00 & 7,33 \\
\hline 61 & 4,92 & 5,25 & 5,57 & 5,90 & 6,23 & 6,56 & \begin{tabular}{ll|}
6,89 \\
\end{tabular} & 7,21 \\
\hline 62 & 4,84 & 5,16 & 5,48 & 5,81 & 6,13 & 6,45 & 6,77 & 7,10 \\
\hline 63 & 4,76 & 5,08 & 5,40 & 5,71 & 6,03 & 6,35 & 6,67 & 6,98 \\
\hline 64 & 4,69 & 5,00 & 5,31 & 5,63 & 5,94 & 6,25 & 6,56 & 6,88 \\
\hline 65 & 4,62 & 4,92 & 5,23 & 5,54 & 5,85 & 6,15 & 6,46 & 6,77 \\
\hline 66 & 4,55 & 4,85 & 5,15 & 5,45 & 5,76 & 6,06 & 6,36 & 6,67 \\
\hline 67 & 4,48 & 4,78 & 5,07 & 5,37 & 5,67 & 5,97 & 6,27 & 6,57 \\
\hline 68 & 4,41 & 4,71 & 5,00 & 5,29 & 5,59 & 5,88 & 6,18 & 6,47 \\
\hline 69 & 4,35 & 4,64 & 4,93 & 5,22 & 5,51 & 5,80 & 6,09 & 6,38 \\
\hline 70 & 4,29 & 4,57 & 4,86 & 5,14 & 5,43 & 5,71 & 6,00 & 6,29 \\
\hline 71 & 4,23 & 4,51 & 4,79 & 5,07 & 5,35 & 5,63 & 5,92 & 6,20 \\
\hline 72 & 4,17 & 4,44 & 4,72 & 5,00 & 5,28 & 5,56 & 5,83 & 6,11 \\
\hline 73 & 4,11 & 4,38 & 4,66 & 4,93 & 5,21 & 5,48 & 5,75 & 6,03 \\
\hline 74 & 4,05 & 4,32 & 4,59 & 4,86 & 5,14 & 5,41 & 5,68 & 5,95 \\
\hline 75 & 4,00 & 4,27 & 4,53 & 4,80 & 5,07 & 5,33 & 5,60 & 5,87 \\
\hline 76 & 3,95 & 4,21 & 4,47 & 4,74 & 5,00 & 5,26 & 5,53 & 5,79 \\
\hline 77 & 3,90 & 4,16 & 4,42 & 4,68 & 4,94 & 5,19 & 5,45 & 5,71 \\
\hline 78 & 3,85 & 4,10 & 4,36 & 4,62 & 4,87 & 5,13 & 5,38 & 5,64 \\
\hline 79 & 3,80 & 4,05 & 4,30 & 4,56 & 4,81 & 5,06 & 5,32 & 5,57 \\
\hline 80 & 3,75 & 4,00 & 4,25 & 4,50 & 4,75 & 5,00 & 5,25 & 5,50 \\
\hline 81 & 3,70 & 3,95 & 4,20 & 4,44 & 4,69 & 4,94 & 5,19 & 5,43 \\
\hline 82 & 3,66 & 3,90 & 4,15 & 4,39 & 4,63 & 4,88 & 5,12 & 5,37 \\
\hline 83 & 3,61 & 3,86 & 4,10 & 4,34 & 4,58 & 4,82 & 5,06 & 5,30 \\
\hline 84 & 3,57 & 3,81 & 4,05 & 4,29 & 4,52 & 4,76 & 5,00 & 5,24 \\
\hline 85 & 3,53 & 3,76 & 4,00 & 4,24 & 4,47 & 4,71 & 4,94 & 5,18 \\
\hline 86 & 3,49 & 3,72 & 3,95 & 4,19 & 4,42 & 4,65 & 4,88 & 5,12 \\
\hline 87 & 3,45 & 3,68 & 3,91 & 4,14 & 4,37 & 4,60 & 4,83 & 5,06 \\
\hline 88 & 3,41 & 3,64 & 3,86 & 4,09 & 4,32 & 4,55 & 4,77 & 5,00 \\
\hline 89 & 3,37 & 3,60 & 3,82 & 4,04 & 4,27 & 4,49 & 4,72 & 4,94 \\
\hline 90 & 3,33 & 3,56 & 3,78 & 4,00 & 4,22 & 4,44 & 4,67 & 4,89 \\
\hline 91 & 3,30 & 3,52 & 3,74 & 3,96 & 4,18 & 4,40 & 4,62 & 4,84 \\
\hline 92 & 3,26 & 3,48 & 3,70 & 3,91 & 4,13 & 4,35 & 4,57 & 4,78 \\
\hline 93 & 3,23 & 3,44 & 3,66 & 3,87 & 4,09 & 4,30 & 4,52 & 4,73 \\
\hline 94 & 3,19 & 3,40 & 3,62 & 3,83 & 4,04 & 4,26 & 4,47 & 4,68 \\
\hline 95 & 3,16 & 3,37 & 3,58 & 3,79 & 4,00 & 4,21 & 4,42 & 4,63 \\
\hline 96 & 3,13 & 3,33 & 3,54 & 3,75 & 3,96 & 4,17 & 4,38 & 4,58 \\
\hline 97 & 3,09 & 3,30 & 3,51 & 3,71 & 3,92 & 4,12 & 4,33 & 4,54 \\
\hline 98 & 3,06 & 3,27 & 3,47 & 3,67 & 3,88 & 4,08 & 4,29 & 4,49 \\
\hline 99 & 3,03 & 3,23 & 3,43 & 3,64 & 3,84 & 4,04 & 4,24 & 4,44 \\
\hline 100 & 3,00 & 3,20 & 3,40 & 3,60 & 3,80 & 4,00 & 4,20 & 4,40 \\
\hline 101 & 2,97 & 3,17 & 3,37 & 3,56 & 3,76 & 3,96 & 4,16 & 4,36 \\
\hline 102 & 2,94 & 3,14 & 3,33 & 3,53 & 3,73 & 3,92 & 4,12 & 4,31 \\
\hline 103 & 2,91 & 3,11 & 3,30 & 3,50 & 3,69 & 3,88 & 4,08 & 4,27 \\
\hline 104 & 2,88 & 3,08 & 3,27 & 3,46 & 3,65 & 3,85 & 4,04 & 4,23 \\
\hline 105 & 2,86 & 3,05 & 3,24 & 3,43 & 3,62 & 3,81 & 4,00 & 4,19 \\
\hline 106 & 2,83 & 3,02 & 3,21 & 3,40 & 3,58 & 3,77 & 3,96 & 4,15 \\
\hline 107 & 2,80 & 2,99 & 3,18 & 3,36 & 3,55 & 3,74 & 3,93 & 4,11 \\
\hline 108 & 2,78 & 2,96 & 3,15 & 3,33 & 3,52 & 3,70 & 3,89 & 4,07 \\
\hline 109 & 2,75 & 2,94 & 3,12 & 3,30 & 3,49 & 3,67 & 3,85 & 4,04 \\
\hline 110 & 2,73 & 2,91 & 3,09 & 3,27 & 3,45 & 3,64 & 3,82 & 4,00 \\
\hline 111 & 2,70 & 2,88 & 3,06 & 3,24 & 3,42 & 3,60 & 3,78 & 3,96 \\
\hline 112 & 2,68 & 2,86 & 3,04 & 3,21 & 3,39 & 3,57 & 3,75 & 3,93 \\
\hline 113 & 2,65 & 2,83 & 3,01 & 3,19 & 3,36 & 3,54 & 3,72 & 3,89 \\
\hline 114 & 2,63 & 2,81 & 2,98 & 3,16 & 3,33 & 3,51 & 3,68 & 3,86 \\
\hline 115 & 2,61 & 2,78 & 2,96 & 3,13 & 3,30 & 3,48 & 3,65 & 3,83 \\
\hline 116 & 2,59 & 2,76 & 2,93 & 3,10 & 3,28 & 3,45 & 3,62 & 3,79 \\
\hline 117 & 2,56 & 2,74 & 2,91 & 3,08 & 3,25 & 3,42 & 3,59 & 3,76 \\
\hline 118 & 2,54 & 2,71 & 2,88 & 3,05 & 3,22 & 3,39 & 3,56 & 3,73 \\
\hline 119 & 2,52 & 2,69 & 2,86 & 3,03 & 3,19 & 3,36 & 3,53 & 3,70 \\
\hline 120 & 2,50 & 2,67 & 2,83 & 3,00 & 3,17 & 3,33 & 3,50 & 3,67 \\
\hline
\end{tabular}

\begin{tabular}{|c|c|c|c|c|c|c|c|c|}
\hline $\begin{array}{l}\text { Lrot } \\
\text { Time (\$) }\end{array}$ & 460 & 480 & 500 & 520 & 540 & 560 & $\mathbf{5 8 0}$ & 600 \\
\hline 60 & 7,67 & 8,00 & 8,33 & 8,67 & 9,00 & 9,33 & 9,67 & 10,00 \\
\hline 61 & 7,54 & 7,87 & 8,20 & 8,52 & 8,85 & 9,18 & 9,51 & 9,84 \\
\hline 62 & 7,42 & 7,74 & 8,06 & 8,39 & 8,71 & 9,03 & 9,35 & 9,68 \\
\hline 63 & 7,30 & 7,62 & 7,94 & 8,25 & 8,57 & 8,89 & 9,21 & 9,52 \\
\hline 64 & 7,19 & 7,50 & 7,81 & 8,13 & 8,44 & 8,75 & 9,06 & 9,38 \\
\hline 65 & 7,08 & $\begin{array}{ll}7,38 \\
\end{array}$ & 7,69 & 8,00 & 8,31 & 8,62 & 8,92 & 9,23 \\
\hline 66 & 6,97 & 7,27 & 7,58 & 7,88 & 8,18 & 8,48 & 8,79 & 9,09 \\
\hline 67 & 6,87 & 7,16 & 7,46 & 7,76 & 8,06 & 8,36 & 8,66 & 8,96 \\
\hline 68 & 6,76 & 7,06 & 7,35 & 7,65 & 7,94 & 8,24 & 8,53 & 8,82 \\
\hline 69 & 6,67 & 6,96 & 7,25 & 7,54 & 7,83 & 8,12 & 8,41 & 8,70 \\
\hline 70 & 6,57 & 6,86 & 7,14 & 7,43 & 7,71 & 8,00 & 8,29 & 8,57 \\
\hline 71 & 6,48 & 6,76 & 7,04 & 7,32 & 7,61 & 7,89 & 8,17 & 8,45 \\
\hline 72 & 6,39 & 6,67 & 6,94 & 7,22 & 7,50 & 7,78 & 8,06 & 8,33 \\
\hline 73 & 6,30 & 6,58 & 6,85 & 7,12 & 7,40 & 7,67 & 7,95 & 8,22 \\
\hline 74 & 6,22 & 6,49 & 6,76 & 7,03 & 7,30 & 7,57 & 7,84 & 8,11 \\
\hline 75 & 6,13 & 6,40 & 6,67 & 6,93 & 7,20 & 7,47 & 7,73 & 8,00 \\
\hline 76 & 6,05 & 6,32 & 6,58 & 6,84 & 7,11 & 7,37 & 7,63 & 7,89 \\
\hline 77 & 5,97 & 6,23 & 6,49 & 6,75 & 7,01 & 7,27 & 7,53 & 7,79 \\
\hline 78 & 5,90 & 6,15 & 6,41 & 6,67 & 6,92 & 7,18 & 7,44 & 7,69 \\
\hline 79 & 5,82 & 6,08 & 6,33 & 6,58 & 6,84 & 7,09 & 7,34 & 7,59 \\
\hline 80 & 5,75 & 6,00 & 6,25 & 6,50 & 6,75 & 7,00 & 7,25 & 7,50 \\
\hline 81 & 5,68 & 5,93 & 6,17 & 6,42 & 6,67 & 6,91 & 7,16 & 7,41 \\
\hline 82 & 5,61 & 5,85 & 6,10 & 6,34 & 6,59 & 6,83 & 7,07 & 7,32 \\
\hline 83 & 5,54 & 5,78 & 6,02 & 6,27 & 6,51 & 6,75 & 6,99 & 7,23 \\
\hline 84 & 5,48 & 5,71 & 5,95 & 6,19 & 6,43 & 6,67 & 6,90 & \\
\hline 85 & 5,41 & 5,65 & 5,88 & 6,12 & 6,35 & 6,59 & 6,82 & 7,06 \\
\hline 86 & 5,35 & 5,58 & 5,81 & 6,05 & 6,28 & 6,51 & 6,74 & 6,98 \\
\hline 87 & 5,29 & 5,52 & 5,75 & 5,98 & 6,21 & 6,44 & 6,67 & 6,90 \\
\hline 88 & 5,23 & 5,45 & 5,68 & 5,91 & 6,14 & 6,36 & 6,59 & 6,82 \\
\hline 89 & 5,17 & 5,39 & 5,62 & 5,84 & 6,07 & 6,29 & 6,52 & 6,74 \\
\hline 90 & 5,11 & 5,33 & 5,56 & 5,78 & 6,00 & 6,22 & 6,44 & 6,67 \\
\hline 91 & 5,05 & 5,27 & 5,49 & 5,71 & 5,93 & 6,15 & 6,37 & 6,59 \\
\hline 92 & 5,00 & 5,22 & 5,43 & 5,65 & 5,87 & 6,09 & 6,30 & 6,52 \\
\hline 93 & 4,95 & 5,16 & 5,38 & 5,59 & 5,81 & 6,02 & 6,24 & 6,45 \\
\hline 94 & 4,89 & 5,11 & 5,32 & 5,53 & 5,74 & 5,96 & 6,17 & 6,38 \\
\hline 95 & 4,84 & 5,05 & 5,26 & 5,47 & 5,68 & 5,89 & 6,11 & 6,32 \\
\hline 96 & 4,79 & 5,00 & 5,21 & 5,42 & 5,63 & 5,83 & 6,04 & 6,25 \\
\hline 97 & 4,74 & 4,95 & 5,15 & 5,36 & 5,57 & 5,77 & 5,98 & 6,19 \\
\hline 98 & 4,69 & 4,90 & 5,10 & 5,31 & 5,51 & 5,71 & 5,92 & 6,12 \\
\hline 99 & 4,65 & 4,85 & 5,05 & 5,25 & 5,45 & 5,66 & 5,86 & 6,06 \\
\hline 100 & 4,60 & 4,80 & 5,00 & 5,20 & 5,40 & 5,60 & 5,80 & 6,00 \\
\hline 101 & 4,55 & 4,75 & 4,95 & 5,15 & 5,35 & 5,54 & 5,74 & 5,94 \\
\hline 102 & 4,51 & 4,71 & 4,90 & 5,10 & 5,29 & 5,49 & 5,69 & 5,88 \\
\hline 103 & 4,47 & 4,66 & 4,85 & 5,05 & 5,24 & 5,44 & 5,63 & 5,83 \\
\hline 104 & 4,42 & 4,62 & 4,81 & 5,00 & 5,19 & 5,38 & 5,58 & 5,77 \\
\hline 105 & 4,38 & 4,57 & 4,76 & 4,95 & 5,14 & 5,33 & 5,52 & 5,71 \\
\hline 106 & 4,34 & 4,53 & 4,72 & 4,91 & 5,09 & 5,28 & 5,47 & 5,66 \\
\hline 107 & 4,30 & 4,49 & 4,67 & 4,86 & 5,05 & 5,23 & 5,42 & 5,61 \\
\hline 108 & 4,26 & 4,44 & 4,63 & 4,81 & 5,00 & 5,19 & 5,37 & 5,56 \\
\hline 109 & 4,22 & 4,40 & 4,59 & 4,77 & 4,95 & 5,14 & 5,32 & 5,50 \\
\hline 110 & 4,18 & 4,36 & 4,55 & 4,73 & 4,91 & 5,09 & 5,27 & 5,45 \\
\hline 111 & 4,14 & 4,32 & 4,50 & 4,68 & 4,86 & 5,05 & 5,23 & 5,41 \\
\hline 112 & 4,11 & 4,29 & 4,46 & 4,64 & 4,82 & 5,00 & $\begin{array}{l}5,18 \\
\end{array}$ & 5,36 \\
\hline 113 & 4,07 & 4,25 & 4,42 & 4,60 & 4,78 & 4,96 & 5,13 & 5,31 \\
\hline 114 & 4,04 & 4,21 & 4,39 & 4,56 & 4,74 & 4,91 & 5,09 & 5,26 \\
\hline 115 & 4,00 & 4,17 & 4,35 & 4,52 & 4,70 & 4,87 & 5,04 & 5,22 \\
\hline 116 & 3,97 & 4,14 & 4,31 & 4,48 & 4,66 & 4,83 & 5,00 & 5,17 \\
\hline 117 & 3,93 & 4,10 & 4,27 & 4,44 & 4,62 & 4,79 & 4,96 & 5,13 \\
\hline 118 & 3,90 & 4,07 & 4,24 & 4,41 & 4,58 & 4,75 & 4,92 & 5,08 \\
\hline 119 & 3,87 & 4,03 & 4,20 & 4,37 & 4,54 & 4,71 & 4,87 & 5,04 \\
\hline 120 & 3,83 & 4,00 & 4,17 & 4,33 & 4,50 & 4,67 & 4,83 & 5,00 \\
\hline
\end{tabular}

Tab. 5. Matrix for calculating the values of the variable $\boldsymbol{n}$ (part 2) 
There is a significant simplification of the standard methodology by merging stages of calculation, as described and exemplified in section 4. There is also a reduction of time allocated to punctual water speed measurements by aggregation of some steps of the initial methodology: the number of signals $(s)$; the number of readings at the timer; the sum of the propeller rotations

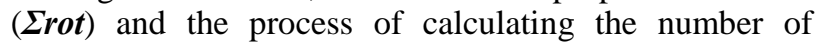
propeller rotations $(\boldsymbol{n})$. Also noticeable is the fact that most of the errors are due to human operators produced during the above-mentioned stages of the algorithm, so merging stages according to the method we propose in this article would eliminate them.

The methodology here presented is applicable to any classical current-meter, the matrix we propose being possible to be built once the calibrating equations are known. The matrix can be adapted for measurements with sum of rotations ranging from 200 to 300 , but involving timed sampling period between 50 and 70 seconds (i.e. for the rivers crossing plain areas) and from 600 to 700 , but involving sampling time between 100 and 120 seconds (i.e. for the rivers crossing Carpathians and Subcarpathians) [26].

The improved method we propose can be easily assimilated by the existing personnel that operate the hydrological stations since it does not request special training and supplementary costs. Finally, the applicability of this simplified method can be considered an intermediary stage between the methods using any type of classical current-meters and those used for automatic stations.

As for further actions, the authors intend to find out whether more substantial improvements can be made. The research described in this paper will lead to an increase in efficiency of the work of the hydrometrical operators and to elimination of the errors during measurements.

The simplified method ant the corresponding matrix keeps being practical since economical difficulties will persist, thus drastically prolonging the scheduled programs for modern equipments acquisition and staff training.

The next step we intend to make is to realize a new matrix, designed for the calibration equation (2) that will allow operators to directly find out the punctual speeds. In the calculation example presented in section 4, this new matrix will practically substitute the stage implying application of equation 7 . We intend to make a large enough number of field experiments to see whether the new matrix is applicable to any calibration equation, inclusively for other types of current-meters.

\section{REFERENCES}

[1] Zăvoianu, I. (2007). Prelucrarea datelor hidrometeorologice (Hydro-metheorological data processing), Editura Fundatiei România de Mâine, ISBN 978-973-725-890-8, Bucharest

[2] Kiselev P. G. (1998). Indrumar pentru calcule hidraulice (Guidebook for hydraulic calculations), Editura Tehnică, Bucharest

[3] ***, (1998), The Decree of the Ministry of Waters, Forests and Environment Protection 358/1998 regarding the approbation of "The Reference Book for the Hydrometric Stations on Romania's Rivers", Official Monitor No. 280/July, 29, 1998, Bucharest
[4] $* * *,(1996)$. The Decree of the Ministry of Waters, Forests and Environment Protection 77/1996 regarding the approbation of "The Reference Book for Organizing and the Program of the Hydrometrical Activities on Rivers", Bucharest

[5] ***, (1997). The Decree of the Ministry of Waters, Forests and Environment Protection 56/1997 regarding the approbation of "The Reference Book for Hydrometric Stations and Activities. Water Discharges and Load", Bucharest

[6] Ghinescu Andreea, (2009), Sisteme de monitorizare in timp real pe raurile din Romania (Systems for real time monitoring of Romania's rivers), Available from: http://www.mmediu.ro/vechi/departament_ape/gospodarirea_apel or/inundatii/prezentari-noiembrie-2009/Andreea\%20GhinescuSISTEME\%20DE\%20MONITORIZARE\%20IN\%20TIMP\%20R EAL\%20PE\%20RAURILE\%20din\%20Romania.ppt\%20[Compat ibility\%20Mode].pdf Accessed: 2012-09-22

[7] Musy, A (1998). Hydrologie appliquée, Editura HGA, Bucharest

[8] Diaconu, C., Şerban, P., (1994). Sinteze si regionari hidrologice (Hydrological regionalizations and syntheses), Editura Tehnică, ISBN 973-31-0638-0, Bucharest

[9] Giurma I., Craciun I., Giurma-Handley R-C. (2001). Hidrologie si hidrogeologie- aplicatii (Hydrology and Hydrogeology, applications), Editura “Gh.Asachi”, ISBN: 973-8050-98-7, Iasi

[10] Giurma I., Craciun I., Giurma-Handley R-C. (2006). Hidrologie, Editura "Gh.Asachi", Iasi

[11] ***, (1963). Instructiuni pentru reteaua hidrometrica de baza (Instructions for basic hydrometrical network, CSA - Institute for Hydrotehnical studies and researches, Bucharest

[12] $* * *,(1998)$. Technical instructions for the use of the currentmeter type MH-2, Institute for Environmental Research and Engineering, MAPPM, Sibiu

[13] Şerban, P., Stănescu, V.A., Roman, P. (1989). Hidrologie dinamică (Dinamic Hydrology), Editura Tehnică, Bucharest

[14] Vladimirescu, I. (1984). Bazele hidrologiei tehnice (Basis of thechnical Hydrology), Ed.Tehnică, Bucharest

[15] Şerban, P., Drobot, R. (1999). Aplicaţii de hidrologie şi gospodărirea apelor (Applications of hydrology and water management), Editura HGA, Bucharest

[16] Luca M. (1988). Hidraulică tehnică, vol. 1 (Thechnical Hydraulics, volume 1), Editura Cermi, Iasi

[17] Diaconu, C. (1999). Hidrometrie aplicată (Applied Hydrometry), Editura HGA, ISBN 9739895441, Bucharest

[18] Drobot R. (1997). Bazele statistice ale hidrologiei (Statistical Bases of Hydrology), Editura Didactica si pedagogica, R.A., ISBN 973-30-4832-1, Bucharest

[19] Zăvoianu, I. (2006). Hidrologie (Hydrology), Editura Fundatiei România de Mâine, ISBN 973-725-716-2, Bucharest

[20] Popa R. (1997). Elemente de hidrodinamica râurilor (Elements of river Hydrodinamics), Editura Didactica si Pedagogica, R.A., Bucharest

[21] * **(1983). Geografia României vol I, Geografia fizică (Geography of Romania vol. I, Physical Geograpy), Editura Academiei Române, CZ 5514 (498) (021), Bucharest

[22] *** (1971), Râurile României - Monografie hidrologică (Rivers of Romania - Hydrological Monography), (coord. Diaconu C.), IMH, Bucharest

[23] Ujvari I. (1972). Geografia apelor României (Geography of Romania's Waters), Editura Ştiinţifică, Bucharest

[24] *** DESWAT PROJECT (Destructive Water Abatment and Control) pentru reducerea impactului inundatiilor prin asigurarea veghii hidrologice continue asupra raurilor si prognozarea viiturilor (2012), Available from: http://www.mmediu.ro/vechi/departament_ape/gospodarirea_apel or/deswat.pdf Accessed: 2012-09-10

[25] Vartolomei, F. (2009). Method for Improvement of Parameter's Precision Used on Hydrological Synthesis in the Romanian Side of the Prut Basin (2009). 1781-1783, Annals of DAAAM for 2009 \& Proceedings of the 20th International DAAAM Symposium, ISBN 978-3-901509-70-4, ISSN 1726-9679, pp 891, Editor B[ranko] Katalinic, Published by DAAAM International, Vienna, Austria 2009

[26] Ujvari I. (1959). Hidrografia R. P. Române (Hydrography of P. R. Odf Romania), Editura Ştiinţifică, Bucharest 